\title{
“MELILITE” IN KIMBERLITES
}

\author{
Skinner, E.M.W. ${ }^{1}$, Mahotkin, I.L. ${ }^{2}$ and Grutter, H.S. ${ }^{3}$
}

1. Geology Department, Rhodes university, Grahamstown 6140, South Africa.

2. DeBeers Centenary Ltd., 3rd Floor, Ul. Tverskaya 22A, 103050 Moscow, Russia.

3. Anglo American Research Laboratories, P.O.Box 106, Crown Mines 2025, South Africa.

The possible presence of melilite in kimberlites has intrigued petrologists for some time, but there are some who believe that it does not exist in kimberlites (Mitchell, 1970 and 1986). Russian authors have for many years reported its presence in Siberian kimberlites (eg. Milashev ,1963). This study shows that pseudomorphs after probable melilite are a relatively abundant, primary constituent of many kimberlites of both poorly micaceous and micaceous types (Groups I \& II). Previous problems with recognition stem from the fact that this mineral is almost ubiquitously altered, but fresh melilite has been identified in Indian kimberlites (eg. Scott Smith, 1989). Melilite as a primary mineral in kimberlites can no longer be ignored, particularly now with the relatively new discovery ( ie. new to the West) of the Archangelsk province of intermediate type kimberlites in Russia (Mahotkin and Skinner, in press).

In Group I kimberlites, melilite pseudomorphs ("melilite") tend to be relatively abundant in the juvenile lapilli of some diatreme-facies kimberlites (eg Ebenhaezer and Koffiefontein kimberlites, RSA). It is less abundant or absent in related, hypabyssal-facies rocks associated with the same occurrence, but, in some Group 1 hypabyssal-facies kimberlites, "melilite" is relatively abundant (eg. in dykes in the Saaiplaas Gold Mine, RSA). In Group I kimberlites with relatively abundant "melilite" in the juvenile lapilli of diatreme-facies rocks, monticellite tends to be the dominant mineral in both the lapilli and in the hypabyssal-facies rocks from the same occurrence. The same situation is apparent in the Archangelsk intermediate type kimberlites, but in the Archangelsk pipe itself, pseudomorphs after possible kalsilite have now been identified within juvenile lapilli. In this case, kalsilite occurs alone and monticellite and melilite are absent. Intermediate type kimberlites, such as the Pionerskaya pipe, Archangelsk district, Russia, follow the same pattern as observed in the Group 1 kimberlites.

In Group II kimberlites (eg Finsch Mine) "melilite" may be relatively abundant in both diatreme- and hypabyssal-facies rocks found in the same pipe complex. In Group II kimberlites with relatively abundant "melilite" in juvenile lapilli, phlogopite is the dominant mineral in both the diatreme- and hypabyssal-facies rocks. Monticellite, previously considered to be absent in Group II kimberlites, occurs in some hypabyssal-facies but not in diatreme-facies rocks.

Under hypabyssal-facies conditions, melilite crystallizes after olivine and early phlogopite, just after or at the same time as diopside, but before monticellite. Under diatreme-facies conditions, melilite crystallizes after early phlogopite but before monticellite and quenched, microlitic dioposide and phlogopite; suggesting that melilite crystallizes before the quenching event. In Group II kimberlites "melilite" crystals tend to be slightly coarser-grained within diatreme-facies, juvenile lapilli $(<0,35 \mathrm{~mm}$.) than within related hypabyssal-facies rocks $(<0.27 \mathrm{~mm})$, suggesting that crystallization 
conditions are more favourable under diatreme-facies conditions. In both hypabyssal- and diatreme facies rocks most "melilite" laths exhibit a slender habit but are not acicular, further supportir crystallization prior to the onset of quenched crystallization. Mineral associations and textures sugge near-surface, low-pressure crystallizing conditions with temperatures in excess of 900 degrees $C$ in th case of diateme-zones and probably in excess of 1000 degrees $C$ within root-zones.

Experimental work by Yoder (1975) indicates that melilite is an unlikely phase in kimberlites unles extensive degassing of the $\mathrm{CO} 2$-rich kimberlitic fluids had occurred. Presumably this is the reason wh melilite occurs in the diatreme-facies but not in the hypabyssal-facies rocks of Group I kimberlite Bulk compositional differences between hypabyssal- and diatreme-facies kimberlites are related main to an absence of calcite and an increase in serpentine and diopside in the case of diatreme-facies rock. For example; a Group I, calcite- phlogopite- monticellite, macrocrystic kimberlite of the hypabyssa facies could change into a phlogopite, "melilite", serpentine, clinopyroxene, tuffisitic kimberlite of th diatreme-facies, as a consequence of degassing and explosive fluidization. The situation is different the more potassic Group II kimberlites where "melilite" is relatively abundant in both facies types

The kalsilite-based normative tetrahedron of Yoder (1986) contains most of the mineral componen found in both hypabyssal and diatreme-facies kimberlites of all types and groupings. Most Group kimbertlites containing melilite plot in the $\mathrm{Fo}+\mathrm{Ph}+\mathrm{Mo}+\mathrm{Ak}$ sub-tetrahedron whereas most Group kimberlites containing melilite plot in the $\mathrm{Fo}+\mathrm{Ph}+\mathrm{Ak}+\mathrm{Di}$ sub-tetrahedron (re. Fig 1). Thes assemblages are consistent with higher bulk $\mathrm{SiO} 2$ contents in Group II kimberlites compared wir Group I kimberlites (Skinner, 1989).

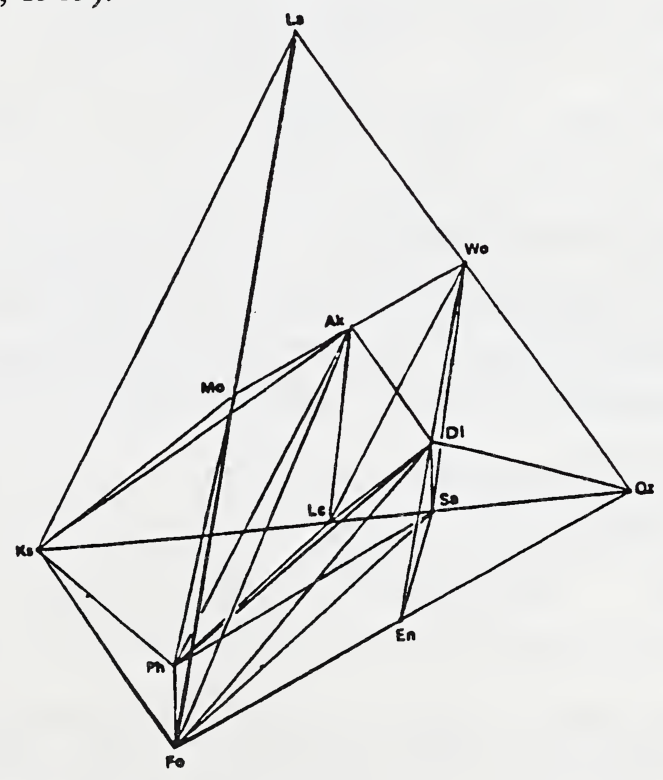

Fig. 1. Normative tetrahedron for compositions in the system $\mathrm{Ks}-\mathrm{La}-\mathrm{Fo}-\mathrm{Qz}$, modified to include melilite and mic (projected from $\mathrm{H}_{2} \mathrm{O}$ ). Ak = akermanite, $\mathrm{Di}=$ Diopside, $\mathrm{En}=$ Enstatite, Fo $=$ Forsterite, $\mathrm{Ks}=\mathrm{Kalsilite}, \mathrm{La}=\mathrm{Lamite}$, $\mathrm{Lc}=$ Leucite, $\mathrm{Mo}=$ Monticellite, $\mathrm{Ph}=\mathrm{Phlogopite}, \mathrm{Qz}=\mathrm{Quartz}, \mathrm{Sa}=$ Sanidine, and $\mathrm{Wo}_{\mathrm{O}}=$ Wollastonite .

Copied from Yoder, 1986. 
The high volatile contents of kimberlites and particularly the water-saturated state of diatreme-facies types results in the instability of melilite as well as other minerals including olivine, monticellite and kalsilite. Melilite is altered mainly to serpentine but other alteration products include chlorite, diopside and carbonate and clay minerals. Altered melilite is present up to $20 \mathrm{vol} . \%$ and as such may be a dominant mineral in some kimberlites (re. Table 1). It deserves to be included in any classification scheme or definition of kimberlite.

Table 1. Modal analyses of selected, melilite-bearing kimberlites.

\begin{tabular}{|l|c|c|c|c|c|c|c|c|c|c|c|c|c|}
\hline \multicolumn{1}{|c|}{ Specimen } & Facies & Gp & $\begin{array}{c}\text { Oli- } \\
\text { vine }\end{array}$ & Phlog. & Diop. & Mont. & $\begin{array}{c}\text { Cal- } \\
\text { cite }\end{array}$ & Serp. & $\begin{array}{c}\text { Meli- } \\
\text { lite }\end{array}$ & Opaque & Perov & $\begin{array}{c}\text { Apa- } \\
\text { tite }\end{array}$ & Other \\
\hline New Elands (33) & H & II & 37 & 36 & 6 & & 4 & 4 & 12 & 1 & & & \\
\hline Saaiplaas (7) & H & I & 39 & 16 & 6 & & 6 & & 20 & 7 & 5 & 1 & \\
\hline Koffiefontein (19) & H & I & 38 & 20 & 2 & 3 & 2 & 11 & 19 & 4 & 1 & & \\
\hline & & & & & & & & & & & & & \\
\hline Finsch-F3 & H & II & 52 & 33 & 8 & & 2 & & 4 & 1 & tr. & tr. & \\
\hline Finsch NE dyke & H & II & 55 & 25 & 6 & 7 & 1 & 2.5 & 2.5 & 1 & tr. & & \\
\hline Finsch-F4 & H & II & 43 & 31 & 8 & & 2 & 4 & 11 & 1 & & & \\
\hline Finsch-F7 & H & II & 41 & 34 & & & 1 & 10 & 11 & 2 & 1 & & \\
\hline Finsch-F9 & H & II & 47 & 24 & & 17 & 4 & & 6 & 1 & 1 & tr. & \\
\hline Finsch-F1 & D & I & & & & & & & $14^{*}$ & & & & $86^{*}$ \\
\hline Finsch-F8 & D & II & & & & & & & $20^{*}$ & & & & $80^{*}$ \\
\hline & & & & & & & & & & & & & \\
\hline Glen Ross K143 & D & I & & & & & & & $25^{*}$ & & & & $75^{*}$ \\
\hline
\end{tabular}

* Calculated on an olivine-free basis in juvenile lapilli only.

\section{References:}

Mahotkin, I.L., and Skinner, E.M.W., in press, Classification of Kimberlites from the Archangelsk region - a new look at grouping of kimberlites.

Milashev, V.A., 1963, The term 'kimberlite' and the classification of kimberlitic rocks. Geol. Geofiz. (4),

p. 42-52. (In Russian).

Mitchell, R.H., 1970, Kimberlite and related rocks - a critical reappraisal. Jour.Geol., 78, p. 686-704.

Mitchell, R.H., 1986, Kimberlites. Plenum Press, New York, pp. 442.

Scott Smith, B.H., 1989, Lamproites and Kimberlites in India. Neues Jahrbuch Miner. 161, 2, p. $193-$ 225.

Skinner, E.M.W., 1989, Contrasting Group I and Group II kimberlite petrology: towards a genetic model for kimberlites. Kimberlites And Related Rocks, Vol.1, Proc. $4^{\text {th }}$ Int. Kimb. Conf., Eds. Ross et al., p. 189-205. Geol. Soc. Australia, Special Publication No. 14.

Yoder,Jr. H.S., 1975, Relationships of melilite-bearing rocks to kimberlite: a preliminary report on the system akermanite - CO 2. In : Physics and Chemistry of the Earth,9 (Eds. AhrensL.H., Dawson, J.B., Duncan, A.R. and Erlank, A.J.), p. 883-894. Pergamon Press, Oxford.

Yoder,Jr. H.S., 1986, Potassium-rich Rocks: Phase Analysis and Heteromorphic Relations. Jour. Petrology, Vol. 27, Part 5, pp. 1215-1228. 